\title{
Preparation and application of $\mathrm{g}-\mathrm{C}_{3} \mathrm{~N}_{4}$-ZnS-DNA nanocomposite with enhanced electrocatalytic activity
}

\author{
Xin Zhou, Jing Zou*, Sheng Zhang, Ming Pan, Wanyun Gong \\ School of Chemistry and Environmental Engineering, Key Laboratory for Green Chemical Process of Ministry of Education, Wuhan Institute of Technology, \\ Wuhan 430205, Hubei, China
}

\section{A R T I C L E I N F O}

\section{Article history:}

Received 29 September 2016

Accepted 24 October 2016

Published 5 February 2017

\section{Keywords:}

Graphitic carbon nitride

Zinc sulfide

DNA

Nanocomposite

Electrocatalytic activity

Environmental hormones

\begin{abstract}
A B S T R A C T
We successfully designed and prepared a g- $\mathrm{C}_{3} \mathrm{~N}_{4}$-ZnS-DNA nanocomposite by a simple method and systematically investigated its morphology, microstructure, and electrocatalytic properties. The as-prepared g- $\mathrm{C}_{3} \mathrm{~N}_{4}$-ZnS-DNA nanocomposite possessed the electrocatalytic activity of g- $\mathrm{C}_{3} \mathrm{~N}_{4}-\mathrm{ZnS}$ and the conductivity of DNA. The presence of DNA was found to enhance the electrocatalytic response of the nanocomposite towards environmental hormones, e.g. pentachlorophenol and nonylphenol, owing to the interaction between $\mathrm{g}-\mathrm{C}_{3} \mathrm{~N}_{4}-\mathrm{ZnS}$ and DNA, indicating that a stable nanocomposite was formed. The three components showed synergistic effects during electrocatalysis. Electrochemical impedance spectra indicated that the $\mathrm{g}-\mathrm{C}_{3} \mathrm{~N}_{4}-\mathrm{ZnS}$-DNA nanocomposite dramatically facilitated the electron transfer of a modified electrode. The co-doping of g- $\mathrm{C}_{3} \mathrm{~N}_{4}$ film with $\mathrm{ZnS}$ and DNA doubled the electrochemical response of the modified electrode in comparison with that of unmodified $\mathrm{g}-\mathrm{C}_{3} \mathrm{~N}_{4}$ film. The detection limits $(3 \mathrm{~S} / \mathrm{N})$ of pentachlorophenol and nonylphenol were $3.3 \times 10^{-9} \mathrm{~mol} \mathrm{~L}^{-1}$. Meanwhile, we propose a possible Z-scheme mechanism for electron transfer in the g- $\mathrm{C}_{3} \mathrm{~N}_{4}$-ZnS-DNA nanocomposite and the possible pentachlorophenol and nonylphenol electrocatalytic oxidation mechanism. The g- $\mathrm{C}_{3} \mathrm{~N}_{4}$-ZnS-DNA nanocomposite-modified electrode was demonstrated to be effective for electrochemical sensing of trace environmental hormones in water samples.
\end{abstract}

(C) 2016, Dalian Institute of Chemical Physics, Chinese Academy of Sciences. Published by Elsevier B.V. All rights reserved.

\section{Introduction}

Nanocomposites are a new class of composites and are used in a wide range of applications in various fields, such as catalysis, optoelectronic devices, semiconductor devices, and aerospace and construction [1-3]. The unique two-dimensional layered structure of g- $\mathrm{C}_{3} \mathrm{~N}_{4}$ makes it favorable for coupling with other components to form g- $\mathrm{C}_{3} \mathrm{~N}_{4}$-based nanocomposites with enhanced catalytic performance [4-6]. In particular, combining g- $\mathrm{C}_{3} \mathrm{~N}_{4}$ with semiconductors to improve its conductivity and catalytic performance has attracted wide research interest $[7,8]$. Such g- $\mathrm{C}_{3} \mathrm{~N}_{4}$-based semiconductor nanocomposites have been widely used for the degradation of pollutants, photocatalytic hydrogen generation, and photocatalytic conversion of carbon dioxide to methane fuel. Previous research on the preparation and enhanced photocatalytic properties of these nanocomposites may be briefly summarized as follows. First, g- $\mathrm{C}_{3} \mathrm{~N}_{4}$ couples with a wide band gap semiconductor which responses to ultraviolet (UV) light, including metal oxides, to form efficient and stable photocatalysts. It is well known that

\footnotetext{
* Corresponding author. Tel/Fax: +86-27-81624593; E-mail: jingzou@wit.edu.cn

This work was supported by the National Natural Science Foundation of China (21471122) and Graduate Student Education Innovation Fundation and President Foundation of Wuhan Institute of Technology (CX2015147, 2016062).

DOI: 10.1016/S1872-2067(16)62582-2 | http://www.sciencedirect.com/science/journal/18722067 | Chin. J. Catal., Vol. 38, No. 2, February 2017
} 
$\mathrm{ZnWO}_{4}$ (wide band gap semiconductor) cannot be excited by visible light. However, g- $\mathrm{C}_{3} \mathrm{~N}_{4}-\mathrm{ZnWO}_{4}$ semiconductor photocatalysts fabricated by the Wang et al. [9] and Sun et al. [10] possessed commendably durable photocatalytic activity for the removal of $\mathrm{RhB}$, as well as enhanced photocurrent response under visible light irradiation. Thus, g- $\mathrm{C}_{3} \mathrm{~N}_{4}$-sensitized $\mathrm{ZnWO}_{4}$ photocatalysts exhibit enhanced visible light photocatalytic performance. To further broaden its application, many research groups have developed many new g- $\mathrm{C}_{3} \mathrm{~N}_{4}$ based nanocomposites with superior photocatalytic performance, such as g- $\mathrm{C}_{3} \mathrm{~N}_{4} / \mathrm{TiO}_{2}$ [11-13], g- $\mathrm{C}_{3} \mathrm{~N}_{4} / \mathrm{ZnO}[14,15]$, g- $\mathrm{C}_{3} \mathrm{~N}_{4} / \mathrm{Bi}_{2} \mathrm{WO}_{6}$ [16], g- $\mathrm{C}_{3} \mathrm{~N}_{4} / \mathrm{BiPO}_{4}$ [17], and g- $\mathrm{C}_{3} \mathrm{~N}_{4} / \mathrm{SrTiO}_{3}$ [18]. Second, g- $\mathrm{C}_{3} \mathrm{~N}_{4}$ couples with a narrow band gap semiconductor which responses to visible light, including metal oxides, metal sulfides, and oxyhalides, to form nanocomposites with a new electronic structure. This new electronic structure in turn induces a built-in electric field within the space charge region that spatially separates and migrates the photo-generated electrons and holes [19] for improving visible light catalytic performance and stability. $\mathrm{WO}_{3}$ is a narrow band gap metal oxide semiconductor that can be coupled with g- $\mathrm{C}_{3} \mathrm{~N}_{4}$. The band gaps of $\mathrm{WO}_{3}$ and g- $\mathrm{C}_{3} \mathrm{~N}_{4}$ are 2.65 and $2.70 \mathrm{eV}$, respectively. $\mathrm{WO}_{3}$ and $\mathrm{g}-\mathrm{C}_{3} \mathrm{~N}_{4}$ can be both excited to produce photogenerated electron-hole pairs under visible light irradiation. g- $\mathrm{C}_{3} \mathrm{~N}_{4}-\mathrm{WO}_{3}$ nanocomposites fabricated by a physical mixing method have been used to decontaminate the organic gas pollutant acetaldehyde [20]. The remarkably increased performance of the nanocomposites was mainly ascribed to the synergistic effects of suitable band positions of the components, an enlarged specific surface area, and enhanced optical absorption in the visible region. Additionally, narrow band gap AgX-based photocatalysts have attracted great attention as promising candidates for highly efficient visible light photocatalysis. Novel visible-light-driven g- $\mathrm{C}_{3} \mathrm{~N}_{4}-\mathrm{AgX}(\mathrm{X}=\mathrm{Br}, \mathrm{I})$ nanocomposites have been successfully applied to the removal of methyl orange (MO) [21]. The high photocatalytic activity of g- $\mathrm{C}_{3} \mathrm{~N}_{4}-\mathrm{AgX}(\mathrm{X}=\mathrm{Br}, \mathrm{I})$ nanocomposites was ascribed to the strong coupling between $\mathrm{g}-\mathrm{C}_{3} \mathrm{~N}_{4}$ and $\mathrm{AgX}$, which facilitated interfacial charge transfer and inhibited electron-hole recombination. Owing to the multiple advantages gained by combining g- $\mathrm{C}_{3} \mathrm{~N}_{4}$ with a narrow band gap semiconductor, a host of attempts have been made to exploit novel candidates for coupling with g- $\mathrm{C}_{3} \mathrm{~N}_{4}$ (e.g., g- $\mathrm{C}_{3} \mathrm{~N}_{4}-\mathrm{TaON}$ [22], g- $\mathrm{C}_{3} \mathrm{~N}_{4}-\mathrm{CuGaSe} 2$ [23], g- $\mathrm{C}_{3} \mathrm{~N}_{4}-\mathrm{MoS}_{2}$ [24], g- $\mathrm{C}_{3} \mathrm{~N}_{4}-\mathrm{Co}_{3} \mathrm{O}_{4}$ [25], g- $\mathrm{C}_{3} \mathrm{~N}_{4}-\mathrm{BiOBr}$ [26]). These g- $\mathrm{C}_{3} \mathrm{~N}_{4}$-based nanocomposites have become an important family of visible light photocatalysts for contaminant degradation and hydrogen production.

Although many studies have been recently carried out on the photocatalytic performance of g- $\mathrm{C}_{3} \mathrm{~N}_{4}$-based semiconductor nanocomposites, there are few reports describing its performance in the field of electrocatalysis. Based on our experiences, an external electric field on a g- $\mathrm{C}_{3} \mathrm{~N}_{4}$-based semiconductor nanocomposite-modified electrode can induce a built-in electric field within the space charge region that spatially separates and migrates the electro-generated electrons and holes on the surface of the electrode, resulting in a superior electrocatalytic activity compared with that of pure g- $\mathrm{C}_{3} \mathrm{~N}_{4}$. Meanwhile, the incorporation of DNA molecules in nanocomposites can supply more sites for the immobilization of $\mathrm{ZnS}$ nanosheets, which is favorable for the formation of stable nanocomposites. Therefore, it is expected that the combination of g- $\mathrm{C}_{3} \mathrm{~N}_{4}$ and $\mathrm{ZnS}$ semiconductor nanosheets and DNA will be an opportunity to obtain a novel g- $\mathrm{C}_{3} \mathrm{~N}_{4}$-ZnS-DNA nanocomposite with improved electrocatalytic activity for the determination of hormones in environmental water samples.

In this paper, we prepared $\mathrm{ZnS}$ nanosheets by a solvothermal method and prepared $\mathrm{g}-\mathrm{C}_{3} \mathrm{~N}_{4}-\mathrm{ZnS}$ heterojunctions and a g- $\mathrm{C}_{3} \mathrm{~N}_{4}$-ZnS-DNA nanocomposite by a simple physical-mixing method. The morphology, microstructure, and electrocatalytic properties of the $\mathrm{g}-\mathrm{C}_{3} \mathrm{~N}_{4}-\mathrm{ZnS}$-DNA nanocomposite were comprehensively characterized. Moreover, a g- $\mathrm{C}_{3} \mathrm{~N}_{4}-\mathrm{ZnS}$-DNA nanocomposite-modified electrode exhibited superior electrocatalytic activity for environmental hormones.

\section{Experimental}

\subsection{Preparation of $g-C_{3} N_{4}$, ZnS nanosheets, and g- $C_{3} N_{4}-Z n S$ heterojunctions}

g- $\mathrm{C}_{3} \mathrm{~N}_{4}$ was prepared by heating melamine to $550{ }^{\circ} \mathrm{C}$ for $4 \mathrm{~h}$ under air atmosphere in a muffle furnace. $\mathrm{ZnS}$ nanosheets were synthesized by a solvothermal method. In a typical procedure, zinc acetate dihydrate, acetylacetone, and thioacetamide in a molar ratio of 1:3:3 were each introduced directly into $10 \mathrm{~mL}$ of ethanol under ultrasonication. Next, the acetylacetone solution was added dropwise to the zinc acetate dihydrate solution. The thioacetamide solution was then added dropwise to the above mixture. Finally, the mixed solution was transferred into a $50 \mathrm{~mL}$ Teflon-lined stainless steel autoclave for solvothermal processing at $180^{\circ} \mathrm{C}$ for $24 \mathrm{~h}$ in an electric oven, after which the autoclave was allowed to cool to room temperature naturally. The white crystalline product was collected by centrifugation and washed with water and ethanol several times to remove the excess reactants and by products. The solid product was dried at $60^{\circ} \mathrm{C}$ in air for $4 \mathrm{~h}$ and used in following experiments. g- $\mathrm{C}_{3} \mathrm{~N}_{4}-\mathrm{ZnS}$ heterojunctions were prepared with a stir-mixing method. Amounts of g- $\mathrm{C}_{3} \mathrm{~N}_{4}$ and $\mathrm{ZnS}$ were mixed at a mass ratio of $4: 6$ and dispersed in water under stirring for $48 \mathrm{~h}$. The final product was gathered using a centrifuge, washed with absolute ethanol and ultra-pure water several times, and then dried in a vacuum oven at $70^{\circ} \mathrm{C}$.

\subsection{Preparation of g-C $\mathrm{C}_{3} \mathrm{~N}_{4}$-ZnS-DNA nanocomposite and $g-C_{3} N_{4}-Z n S-D N A-G C E$ modified electrode}

The g- $\mathrm{C}_{3} \mathrm{~N}_{4}$-ZnS-DNA nanocomposite was fabricated as follows: $1.0 \mathrm{mg}$ of g- $\mathrm{C}_{3} \mathrm{~N}_{4}-\mathrm{ZnS}$ heterojunctions was dispersed in 1 mL Herring Sperm DNA solution $\left(1 \mathrm{~g} \mathrm{~L}^{-1}\right)$ under ultrasonication for $30 \mathrm{~min}$.

The g- $\mathrm{C}_{3} \mathrm{~N}_{4}$-ZnS-DNA-GCE modified electrode was prepared using a polymerization method. First, a glassy carbon electrode (GCE) was mechanically polished to a mirror finish with 0.05 $\mu \mathrm{m}$ alumina slurry, rinsed and ultrasonicated in ultra-pure water for $1 \mathrm{~min}$. Then, the surface of the GCE was coated with $5 \mu \mathrm{L}$ of g- $\mathrm{C}_{3} \mathrm{~N}_{4}-\mathrm{ZnS}$-DNA nanocomposite suspension. After drying, 
the electrode was polymerized for 10 cycles in an aniline solution.

All chemicals used were of analytical grade. Pure water (18.2 $\mathrm{M} \Omega \mathrm{cm}$ ) provided by an apparatus (Wuhan Pinguan Instrument Equipment Co. Ltd.) was used in all experiments.

\subsection{Characterization}

The obtained samples were analyzed by transmission electron microscopy (TEM; JEOL JEM-2010), X-ray diffraction (XRD; Bruker D8 Advance TXS), UV-vis diffuse reflectance spectrometry (DRS; Cary Series, Agilent Technologies), and X-ray photoelectron spectrometry (XPS; VG Multilab 2000, Thermo). Cyclic voltammetry (CV) and differential pulse voltammetry (DPV) curves were obtained using a CHI-660C electrochemical workstation (China) in a standard three-electrode configuration. The working electrode was the polyaniline film containing the prepared sample on GCE. An $\mathrm{Hg} / \mathrm{Hg}_{2} \mathrm{Cl}_{2}$ electrode was used as the reference electrode, and the counter electrode was a Pt wire.

\section{Results and discussion}

\subsection{TEM analysis}

The prepared $\mathrm{ZnS}$ nanosheets were found to be monodisperse with an average diameter of ca. $40 \mathrm{~nm}$ (Fig. 1(a)). The nanosheet nature of the ZnS was confirmed by HRTEM (inset of Fig. 1(a), in which the lattice spacing of $0.312 \mathrm{~nm}$ corresponded to the spacing of the (111) plane of $\mathrm{ZnS}$. The as-prepared g- $\mathrm{C}_{3} \mathrm{~N}_{4}$ displayed a micrometer-sized sheet-like structure (Fig. 1(b)). In the g- $\mathrm{C}_{3} \mathrm{~N}_{4}-\mathrm{ZnS}$ heterojunctions, the $\mathrm{ZnS}$ nanosheets were uniformly immobilized on the surface and edges of the g- $\mathrm{C}_{3} \mathrm{~N}_{4}$ sheets (Fig. 1(c)). Fig. 1(d) shows a TEM image of the g- $\mathrm{C}_{3} \mathrm{~N}_{4}$-ZnS-DNA hybrid structure. DNA is a biological macromolecule and has a strong UV absorption at $260 \mathrm{~nm}$ owing to its pyrimidine and purine bases [27]. To confirm the existence
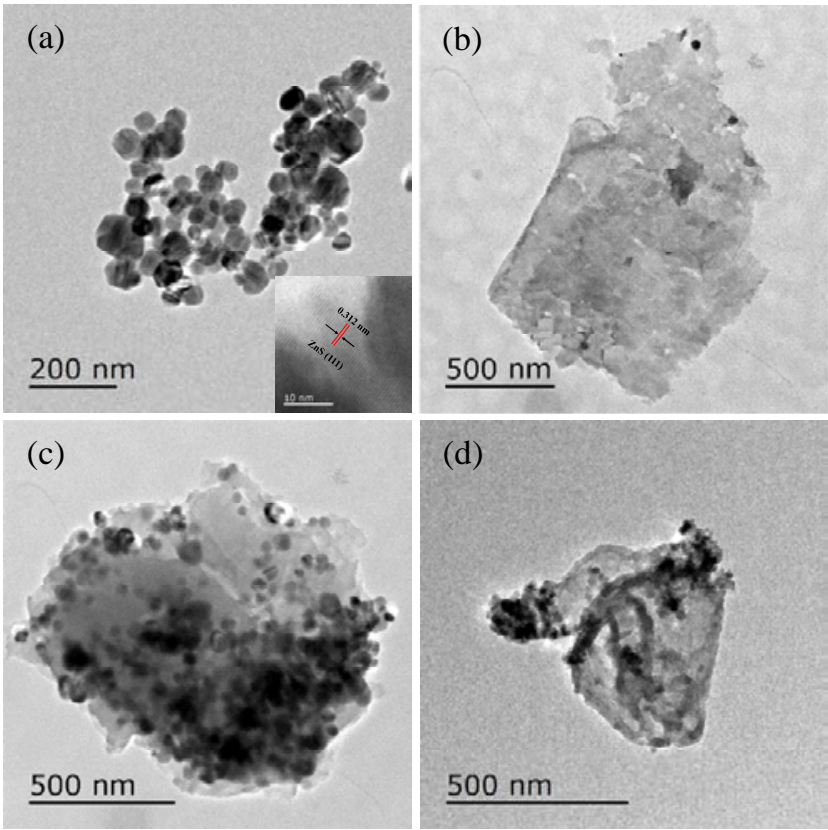

(d)

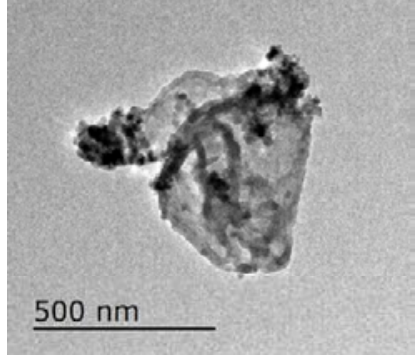

Fig. 1. TEM images of different samples. (a) ZnS nanosheets (inset: HRTEM image); (b) g- $\mathrm{C}_{3} \mathrm{~N}_{4}$; (c) g- $\mathrm{C}_{3} \mathrm{~N}_{4}-\mathrm{ZnS}$ heterojunctions; (d) g- $\mathrm{C}_{3} \mathrm{~N}_{4}$-ZnS-DNA nanocomposite.

of DNA in the nanocomposite, the UV absorption performance of DNA extracted from the nanocomposite with $0.1 \mathrm{~mol} \mathrm{~L}^{-1}$ Tris buffer solution ( $\mathrm{pH}$ 7.1) was studied by UV spectroscopy. As shown in Fig. 2, the $\lambda_{\max }$ of the extraction was found to be 260 $\mathrm{nm}$ in agreement with that of pure DNA, confirming that DNA was present in the nanocomposite as designed. Additionally, the interaction between DNA and PCP or NP was also studied by UV spectroscopy. As shown in Fig. 2(b), the DNA absorption peak exhibited an obvious increase in intensity after the addition of $0.1 \mathrm{mmol} \mathrm{L-1}$ PCP or NP, indicating an interaction between DNA and PCP or NP. In the presence of DNA, the DNA molecules would have become linked to the $\mathrm{g}-\mathrm{C}_{3} \mathrm{~N}_{4}$ surface by $\mathrm{C}-\mathrm{O}-\mathrm{C}$ bonds [28], leading to the assembly of $\mathrm{ZnS}$ nanosheets
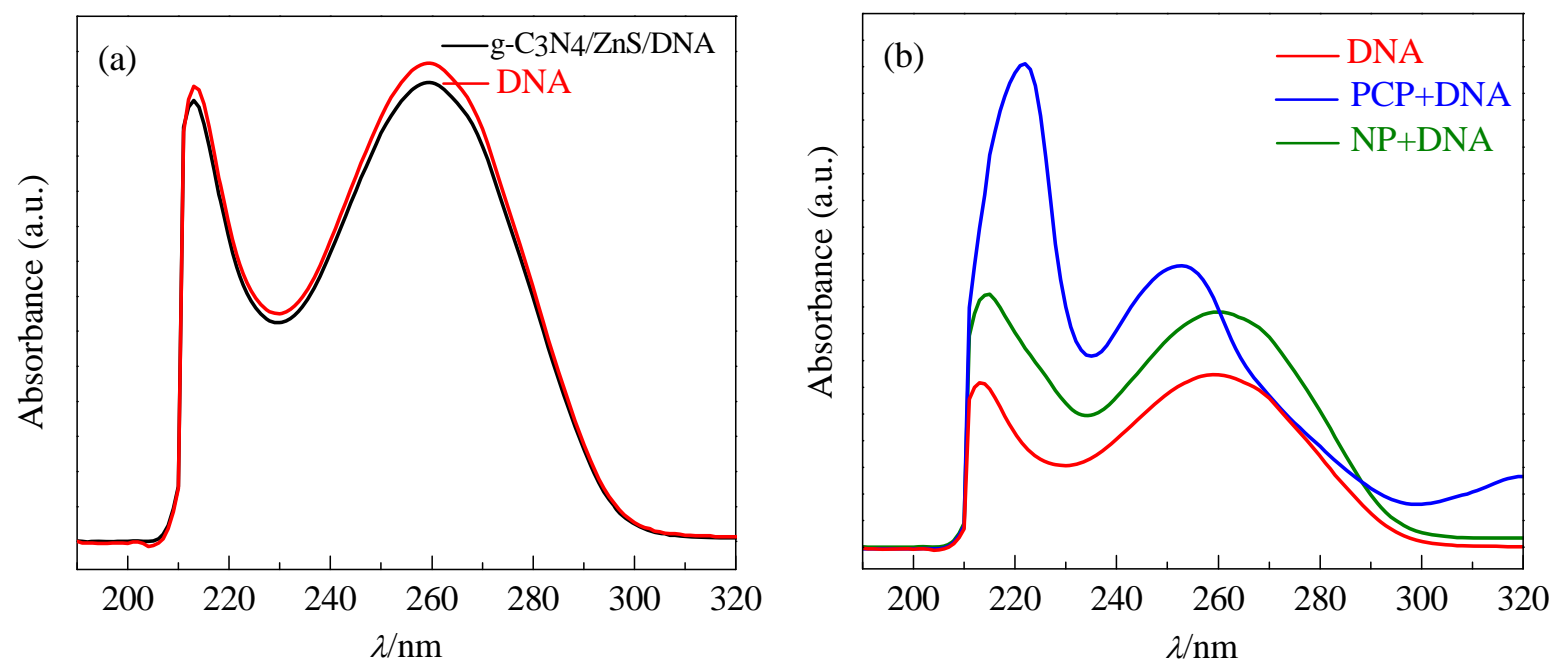

Fig. 2. UV spectra of DNA in nanocomposite and pure DNA (a) and DNA before and after addition of PCP and NP (b) in Tris buffer solution (pH 7.1). 
into linear superstructures. In the absence of DNA, the $\mathrm{ZnS}$ nanosheets were uniformly dispersed. Therefore, the DNA molecules in the nanocomposite supplied more sites for the immobilization of $\mathrm{ZnS}$ nanosheets, leading to the formation of a stable g- $\mathrm{C}_{3} \mathrm{~N}_{4}$-ZnS-DNA nanocomposite.

\subsection{XRD and XPS analyses}

The g- $\mathrm{C}_{3} \mathrm{~N}_{4}, \mathrm{ZnS}$, and the g- $\mathrm{C}_{3} \mathrm{~N}_{4}-\mathrm{ZnS}$ heterojunctions were also characterized by XRD and DRS (Fig. 3). In the XRD pattern of $g-\mathrm{C}_{3} \mathrm{~N}_{4}$, the (100) diffraction at $13.1^{\circ}$ was attributed to interplanar structural packing, while the strong (002) peak at $27.3^{\circ}$ reflected the characteristic interlayer stacking structure [22], indicating that layer-structured $\mathrm{g}-\mathrm{C}_{3} \mathrm{~N}_{4}$ was successfully synthesized. In the ZnS nanosheets, the (111) peak at 28.6 , (220) peak at $47.6^{\circ}$, and (311) peak at $56.4^{\circ}$ were all characteristic of cubic ZnS crystal (JCPDS, 05-0566), suggesting the successful preparation of $\mathrm{ZnS}$. Meanwhile, the g- $\mathrm{C}_{3} \mathrm{~N}_{4}-\mathrm{ZnS}$ heterojunctions exhibited some characteristic diffraction peaks corresponding to both g- $\mathrm{C}_{3} \mathrm{~N}_{4}$ and $\mathrm{ZnS}$, and no impurity diffraction peaks were observed (Fig. 3(a)), indicating that g- $\mathrm{C}_{3} \mathrm{~N}_{4}-\mathrm{ZnS}$ heterojunctions were successfully synthesized.

The electronic structures of the three samples were investigated using DRS. As shown in Fig. 3(b), the ZnS nanosheets only absorbed UV light with wavelength shorter than around 360 $\mathrm{nm}$, representing a band gap of $\sim 3.44 \mathrm{eV}$. g- $\mathrm{C}_{3} \mathrm{~N}_{4}$ exhibited an absorption edge at about $426 \mathrm{~nm}$, corresponding to a band gap of $2.91 \mathrm{eV}$. In contrast, the absorption edge of the g- $\mathrm{C}_{3} \mathrm{~N}_{4}-\mathrm{ZnS}$ heterojunctions extended to $460 \mathrm{~nm}$, which indicated a band gap of only $\sim 2.69 \mathrm{eV}$. Compared with those of g- $\mathrm{C}_{3} \mathrm{~N}_{4}$ and $\mathrm{ZnS}$, the relatively narrow band gap of the g- $\mathrm{C}_{3} \mathrm{~N}_{4}-\mathrm{ZnS}$ heterojunctions could lead to a faster electron transfer rate and more efficient separation and migration of electro-generated electrons and holes at the interface of the heterojunctions. Moreover, electrons can transfer faster through DNA, so the electrocatalytic activity of the g- $\mathrm{C}_{3} \mathrm{~N}_{4}$-ZnS-DNA modified electrode was expected to be improved.
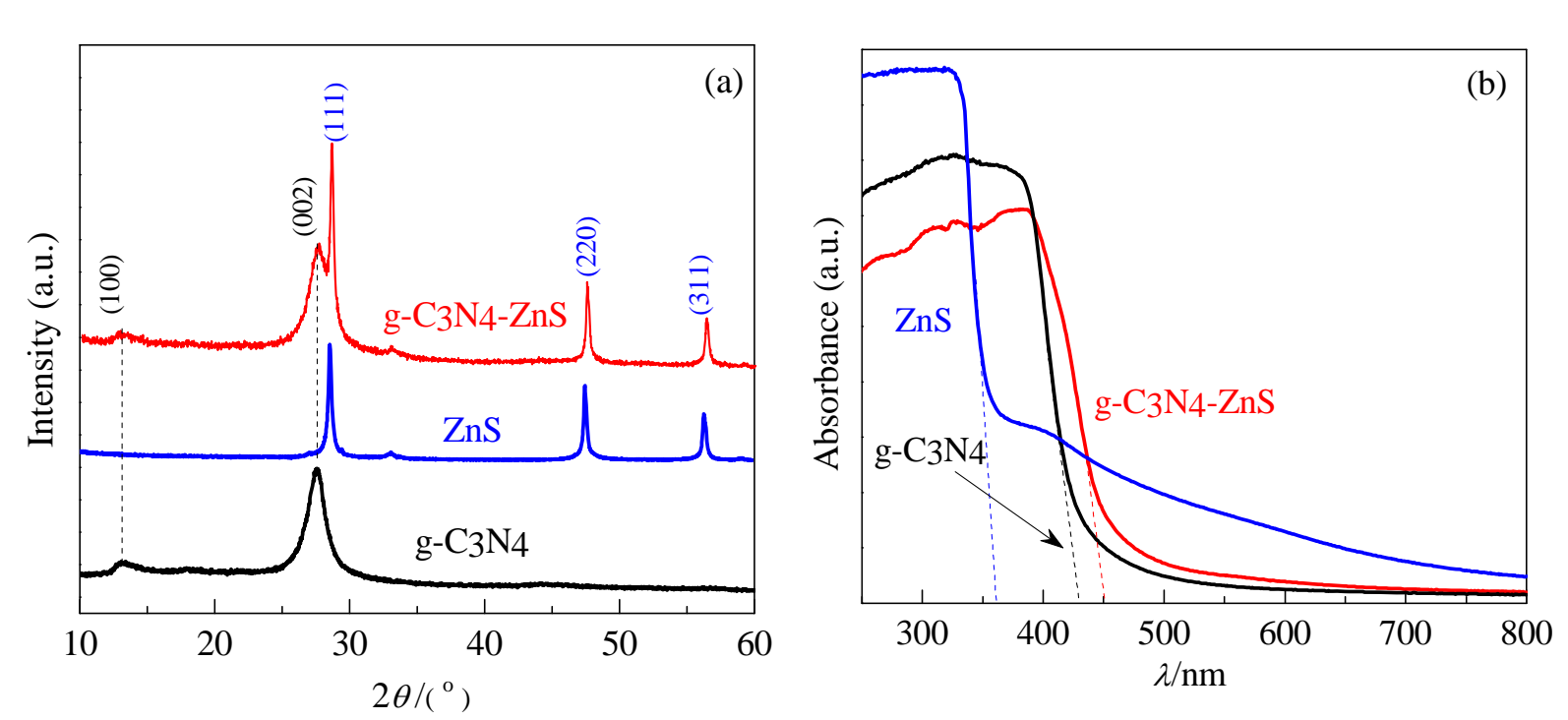

XPS analysis was carried out to further analyze the chemical composition of the g- $\mathrm{C}_{3} \mathrm{~N}_{4}-\mathrm{ZnS}$ heterojunctions and the interaction of $\mathrm{ZnS}$ with the g- $\mathrm{C}_{3} \mathrm{~N}_{4}$ support. Fig. 4(a) shows the full XPS spectra of the $\mathrm{g}-\mathrm{C}_{3} \mathrm{~N}_{4}$ and $\mathrm{g}-\mathrm{C}_{3} \mathrm{~N}_{4}-\mathrm{ZnS}$ heterojunctions. The g- $\mathrm{C}_{3} \mathrm{~N}_{4}$ samples were found to be mainly composed of $\mathrm{C}$ and $\mathrm{N}$. A very weak $01 s$ peak was also observed, which can be ascribed to a tiny amount of $\mathrm{O}_{2}$ adsorbed on the surface of the sample during the polymerization process. Meanwhile, the wide XPS spectrum of the g- $\mathrm{C}_{3} \mathrm{~N}_{4}-\mathrm{ZnS}$ heterojunctions shows that they were mainly composed of $\mathrm{C}, \mathrm{N}, \mathrm{S}$, and $\mathrm{Zn}$ elements. Additionally, the XPS Zn $2 p$ spectrum of the heterojunctions (Fig. 4(d)) could be deconvoluted into two peaks at binding energies of 1022.0 and $1045.1 \mathrm{eV}$, which were attributed to $\mathrm{Zn}$ $2 p_{3 / 2}$ and $2 p_{1 / 2}$, respectively [29]. The binding energy difference of $23 \mathrm{eV}$ indicates that the $\mathrm{Zn}$ ions were in the +2 oxidation state. Meanwhile, the peaks of S $2 p_{3 / 2}$ and S $2 p_{1 / 2}$ located at around 161.9 and $163.3 \mathrm{eV}$ (Fig. 4(e)), respectively, were assigned to sulfur anions in the lattice of $\mathrm{ZnS}$ [30]. The peak at $168.6 \mathrm{eV}$ was attributed to $\mathrm{S} 2 p$ electrons in the $\mathrm{S}-\mathrm{Zn}$ bond from $\mathrm{SO}_{2}$ species trapped in the lattice [31].

The XPS C $1 s$ and N $1 s$ spectra of the heterojunctions and pure g- $\mathrm{C}_{3} \mathrm{~N}_{4}$ were also comprehensively compared (Fig. 4(b) and (c)). The peak at $284.6 \mathrm{eV}$ was exclusively ascribed to the standard reference carbon, while the peak at $287.9 \mathrm{eV}$ was identified as $\mathrm{C}-\mathrm{N}-\mathrm{C}$ coordination [32]. Interestingly, the area of the $\mathrm{C}-\mathrm{N}-\mathrm{C}$ coordination peak of the $\mathrm{g}-\mathrm{C}_{3} \mathrm{~N}_{4}-\mathrm{ZnS}$ heterojunctions was bigger than that of g- $\mathrm{C}_{3} \mathrm{~N}_{4}$ (Fig. 4(b)), suggesting that the g- $\mathrm{C}_{3} \mathrm{~N}_{4}$ microstructure changed after interaction with $\mathrm{ZnS}$ to form heterojunctions. Meanwhile, Fig. 4(c) shows the XPS N $1 s$ spectra of $\mathrm{g}-\mathrm{C}_{3} \mathrm{~N}_{4}$ and the g- $\mathrm{C}_{3} \mathrm{~N}_{4}-\mathrm{ZnS}$ heterojunctions, which could be deconvoluted into three peaks at 398.3, 399.4, and $400.7 \mathrm{eV}$ assigned to pyridinic $\mathrm{N}(\mathrm{C}-\mathrm{N}-\mathrm{C})$, pyrrolic $\mathrm{N}\left(\mathrm{N}-[\mathrm{C}]_{3}\right)$, and graphitic $\mathrm{N}(\mathrm{C}-\mathrm{NH})$, respectively [33]. It is noteworthy that the area of the $398.3 \mathrm{eV}$ peak was larger for the $\mathrm{g}-\mathrm{C}_{3} \mathrm{~N}_{4}-\mathrm{ZnS}$ heterojunctions than the $\mathrm{g}-\mathrm{C}_{3} \mathrm{~N}_{4}$. It is reported that the oxygen reduction reaction (ORR) active sites are created by pyridinic $\mathrm{N}$ involved in triazine rings $(\mathrm{C}-\mathrm{N}-\mathrm{C})$, and the ORR activity of the

Fig. 3. XRD patterns (a) and UV-vis DRS (b) of g- $\mathrm{C}_{3} \mathrm{~N}_{4}, \mathrm{ZnS}$ nanosheets, and g- $\mathrm{C}_{3} \mathrm{~N}_{4}$-ZnS heterojunctions. 

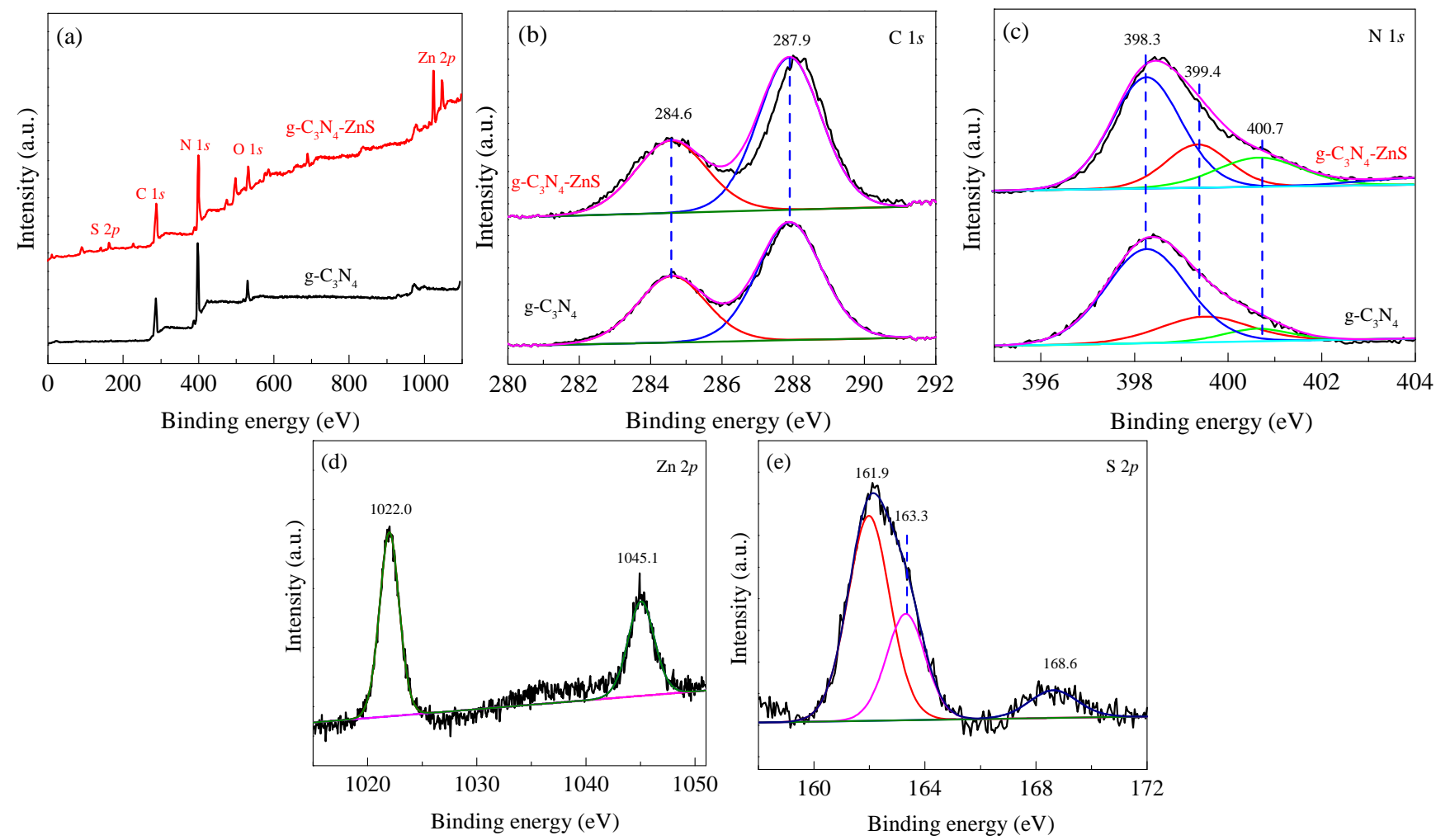

Fig. 4. XPS spectra of g- $\mathrm{C}_{3} \mathrm{~N}_{4}-\mathrm{ZnS}$ heterojunctions and $\mathrm{g}-\mathrm{C}_{3} \mathrm{~N}_{4}$.

catalyst is strongly dependent on the concentration of pyridinic $\mathrm{N}$ [34]. Hence, the increases in the areas of the $\mathrm{C} 1 \mathrm{~s}$ peak at $287.9 \mathrm{eV}$ and the $\mathrm{N} 1 s$ peak at $398.3 \mathrm{eV}$ for the g- $\mathrm{C}_{3} \mathrm{~N}_{4}-\mathrm{ZnS}$ heterojunctions confirmed that the concentration of pyridinic $\mathrm{N}$ in the $\mathrm{g}-\mathrm{C}_{3} \mathrm{~N}_{4}-\mathrm{ZnS}$ heterojunctions was higher than that of $\mathrm{g}-\mathrm{C}_{3} \mathrm{~N}_{4}$, suggesting that its ORR activity was enhanced after interaction with $\mathrm{ZnS}$ to form the heterojunctions. These results also indicate that the g- $\mathrm{C}_{3} \mathrm{~N}_{4}-\mathrm{ZnS}$ heterojunctions should possess enhanced electrocatalytic activity.

\subsection{Electrocatalytic activity and electrocatalytic oxidation}

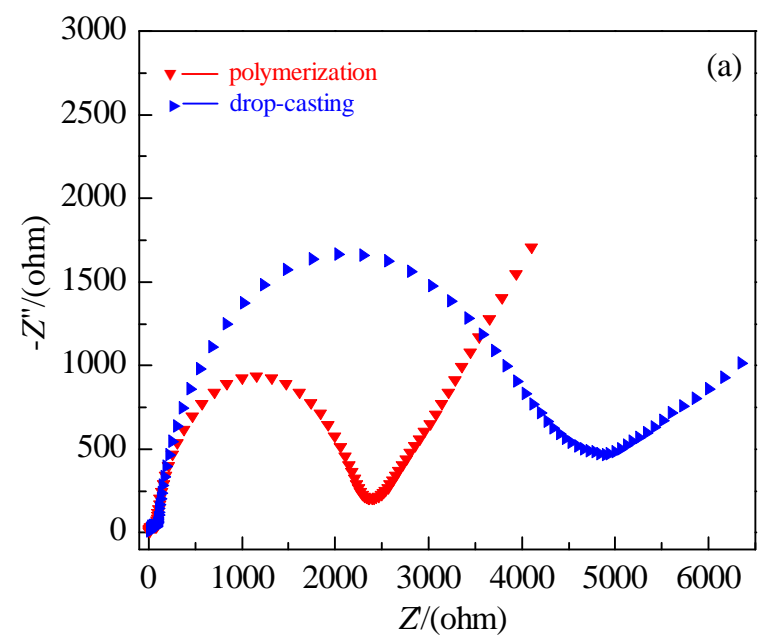

mechanism

Electrochemical impedance spectroscopy (EIS) is a highly effective method for studying the interfacial features of modified electrode surfaces, and may reflect its surface electron transfer resistance (Rct), the improvement of which is an effective approach for performance optimization. To improve the sensitivity of the measurements, we first investigated the electrode modification method. The EIS results for g- $\mathrm{C}_{3} \mathrm{~N}_{4}-\mathrm{ZnS}$-DNA modified GCEs prepared by polymerization and drop coating are shown in Fig. 5(a). The Rct of an g- $\mathrm{C}_{3} \mathrm{~N}_{4}-\mathrm{ZnS}$-DNA-GCE elec-

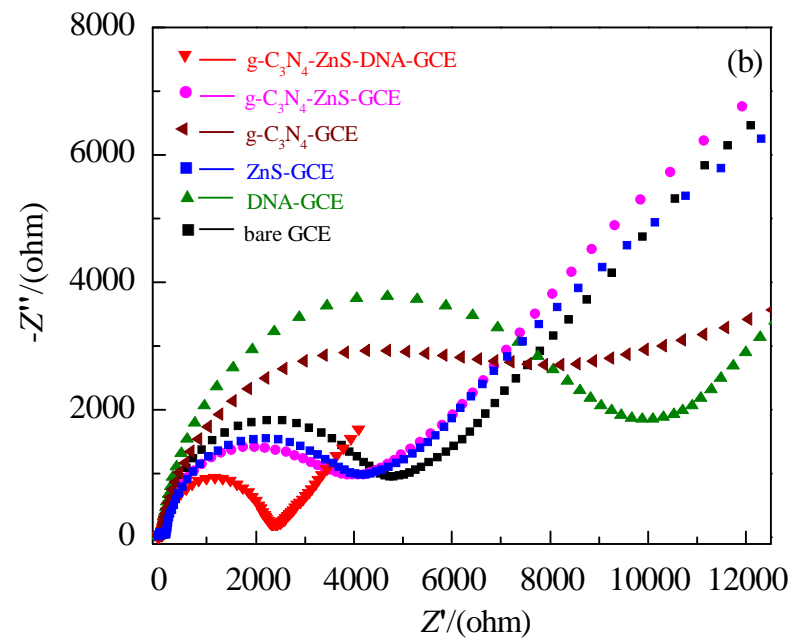

Fig. 5. Electrochemical impedance spectra of g- $\mathrm{C}_{3} \mathrm{~N}_{4}$-ZnS-DNA electrodes modified by different methods (a) and different polyaniline-modified electrodes (b) in $0.05 \mathrm{~mol} \mathrm{~L}^{-1} \mathrm{~K}_{3}\left[\mathrm{Fe}(\mathrm{CN})_{6}\right] / \mathrm{K}_{4}\left[\mathrm{Fe}(\mathrm{CN})_{6}\right]$ solution. 
trode modified with an electropolymerized film of aniline (red curve) was much smaller than that of an electrode modified with a drop coated chitosan film (blue curve), implying that it is easier to transfer electrons at a g- $\mathrm{C}_{3} \mathrm{~N}_{4}$-ZnS-DNA-GCE modified with polyaniline (PA). Therefore, we selected the polymerization modified method for the following investigation.

Fig. 5(b) shows the EIS of six kinds of modified electrodes in $0.05 \mathrm{~mol} \mathrm{~L}^{-1} \mathrm{~K}_{3}\left[\mathrm{Fe}(\mathrm{CN})_{6}\right] / \mathrm{K}_{4}\left[\mathrm{Fe}(\mathrm{CN})_{6}\right]$ solution: DNA-GCE, ZnS-GCE, g- $\mathrm{C}_{3} \mathrm{~N}_{4}-\mathrm{GCE}, \mathrm{g}-\mathrm{C}_{3} \mathrm{~N}_{4}-\mathrm{ZnS}-\mathrm{GCE}$, g- $\mathrm{C}_{3} \mathrm{~N}_{4}$-ZnS-DNA-GCE, and bare GCE. It was apparent that the Rct of g- $\mathrm{C}_{3} \mathrm{~N}_{4}$-ZnS-DNA-GCE was the smallest. This phenomenon indicates that the addition of DNA to the $\mathrm{g}-\mathrm{C}_{3} \mathrm{~N}_{4}-\mathrm{ZnS}$ heterojunctions may promote electron transfer at the modified electrode surface. Fig. 6 shows the CV curves of PCP and NP at the bare GCE, DNA-GCE, ZnS-GCE, g- $\mathrm{C}_{3} \mathrm{~N}_{4}-\mathrm{GCE}$, g- $\mathrm{C}_{3} \mathrm{~N}_{4}-\mathrm{ZnS}$-GCE and g- $\mathrm{C}_{3} \mathrm{~N}_{4}-\mathrm{ZnS}$-DNA-GCE. Similar results were obtained for the electrochemical responses of PCP and NP at the different electrodes. The oxidation peak currents of PCP and NP at g- $\mathrm{C}_{3} \mathrm{~N}_{4}$-ZnS-DNA-GCE were the largest; co-doping of $\mathrm{ZnS}$ and DNA into the g- $\mathrm{C}_{3} \mathrm{~N}_{4}$ film doubled its electrochemical response in comparison with that of g- $\mathrm{C}_{3} \mathrm{~N}_{4}$ film, which indicates that the as-prepared g- $\mathrm{C}_{3} \mathrm{~N}_{4}$-ZnS-DNA nanocomposite possessed better electrocatalytic activity than individual g- $\mathrm{C}_{3} \mathrm{~N}_{4}$, DNA, ZnS nanosheets, and $\mathrm{g}-\mathrm{C}_{3} \mathrm{~N}_{4}-\mathrm{ZnS}$ heterojunctions. The improved electrochemical response could be attributed to the faster electron transfer rate, accelerated diffusion of PCP and NP towards the electrode surface, more efficient separation and migration of the electro-generated electrons and holes at the interface of the g- $\mathrm{C}_{3} \mathrm{~N}_{4}$-ZnS-DNA nanocomposite, and enhanced ORR activity of the g- $\mathrm{C}_{3} \mathrm{~N}_{4}-\mathrm{ZnS}$-DNA nanocomposite. These results show that the electrochemical response at the detection potentials for PCP and NP increased significantly in the presence of the g- $\mathrm{C}_{3} \mathrm{~N}_{4}$-ZnS-DNA nanocomposite film.

The electrocatalytic oxidation mechanism of PCP and NP at the $\mathrm{g}-\mathrm{C}_{3} \mathrm{~N}_{4}$-ZnS-DNA-GCE modified electrode could be explained as follows. (1) DNA molecules were linked to the g- $\mathrm{C}_{3} \mathrm{~N}_{4}$ surface by $\mathrm{C}-\mathrm{O}-\mathrm{C}$ bonds [28] and caused the $\mathrm{ZnS}$ nanosheets to assemble into linear superstructures, forming a stable g- $\mathrm{C}_{3} \mathrm{~N}_{4}-\mathrm{ZnS}$-DNA nanocomposite. (2) Owing to the interaction
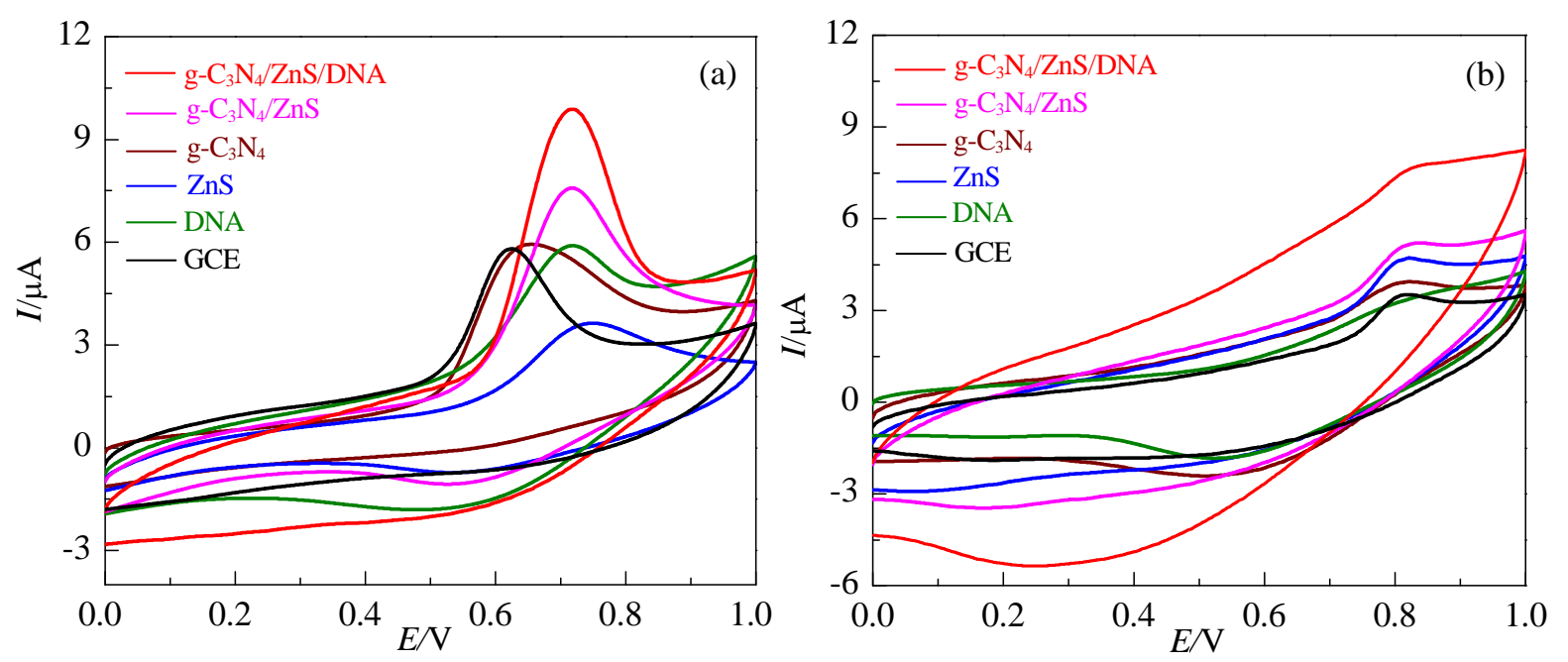

Fig. 6. CV curves of $0.1 \mathrm{mmol} \mathrm{L}^{-1} \mathrm{NP}(\mathrm{a})$ and PCP (b) solutions recorded at different modified electrodes.

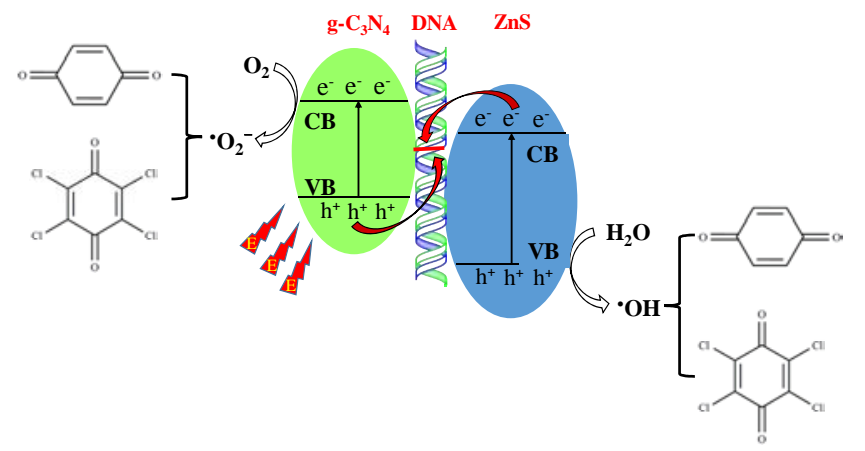

Fig. 7. Possible Z-scheme mechanism for electron transfer in the g- $\mathrm{C}_{3} \mathrm{~N}_{4}$-ZnS-DNA nanocomposite and the possible PCP and NP electrocatalytic oxidation mechanism.

between DNA and PCP or NP, the enhancement in the activity of the electrode may be attributed to an increased concentration of PCP or NP on its surface. (3) PA film carries positive charges, while DNA molecules carry a net negative charge arisings from the numerous phosphate groups within the structure. The overall charge of $\mathrm{g}-\mathrm{C}_{3} \mathrm{~N}_{4}$-ZnS-DNA-GCE was positive. When g- $\mathrm{C}_{3} \mathrm{~N}_{4}-\mathrm{ZnS}$-DNA-GCE was placed in PCP or NP solution $(\mathrm{pH}=$ 6.5), the positively charged surface of the modified electrode absorbed the negatively charged PCP or NP. As a result, the g- $\mathrm{C}_{3} \mathrm{~N}_{4}$-ZnS-DNA nanocomposite PA film promoted electron transfer and accelerated the diffusion of PCP or NP towards the electrode surface. (4) When the catalyst was excited by an electric field, the electrogenerated holes in the VB of $g-\mathrm{C}_{3} \mathrm{~N}_{4}$ shifted to the DNA and annihilated with the electrons generated by ZnS. Thus, the strongly oxidizing electrogenerated holes in the VB of $\mathrm{ZnS}$ participated in the generation of $\bullet \mathrm{OH}$ via the oxidation of $\mathrm{H}_{2} \mathrm{O}$. PCP or NP formed a 4-chlorine quinone or a benzoquinone after electron transfer and $\bullet \mathrm{OH}$ attack. Meanwhile, the strongly reducing electrogenerated electrons in the $\mathrm{CB}$ of $\mathrm{g}-\mathrm{C}_{3} \mathrm{~N}_{4}$ reacted with the $\mathrm{O}_{2}$ absorbed on the surface of the electrode to produce $\bullet_{2}{ }^{-}$, which then reacted with PCP or NP. Through this Z-scheme electron transfer process, the redox ability of the electrogenerated electrons and holes would be increased, and the recombination of the separated electrons 

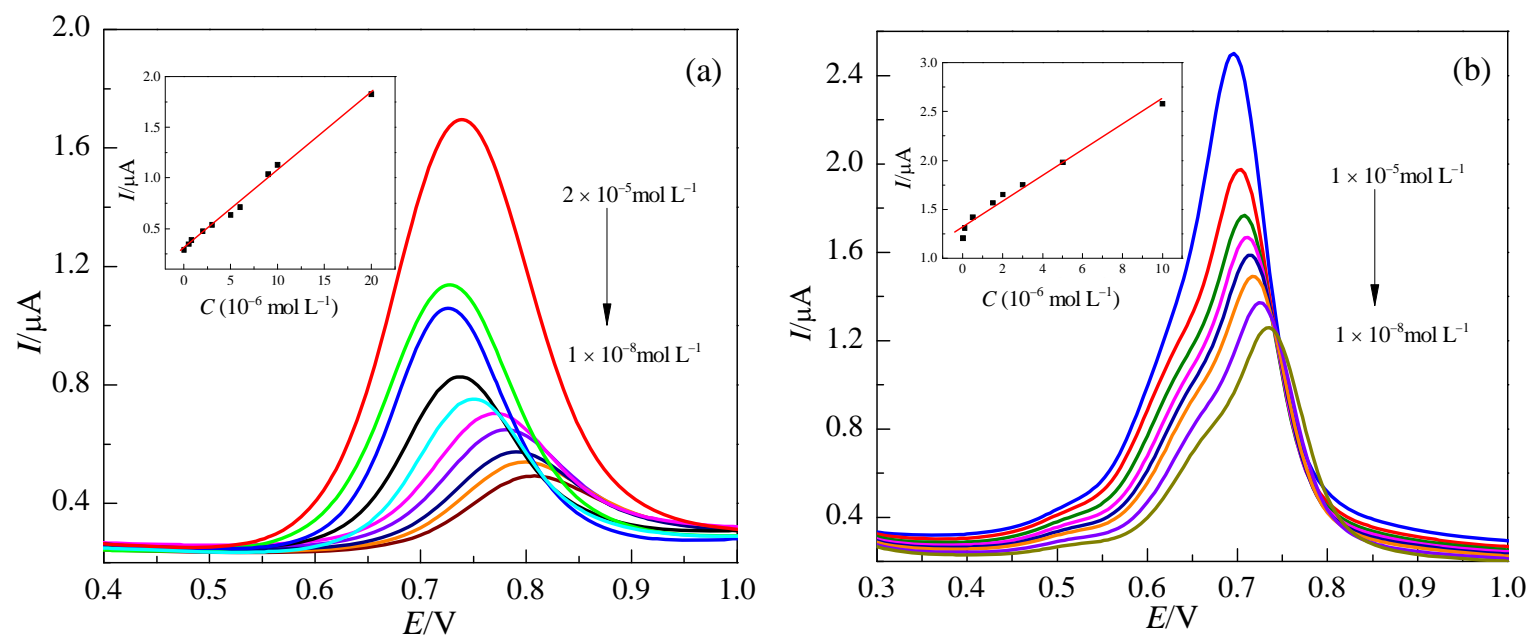

Fig. 8. DPV curves of NP (a) and PCP (b) solutions with different concentrations at g-C $\mathrm{C}_{3} \mathrm{~N}_{4}$-ZnS-DNA-GCE. Insets of (a) and (b) show the relationship between the concentrations of NP and PCP and the DPV peak currents.

and holes would be inhibited, thereby improving the electrocatalytic performance of the $\mathrm{g}-\mathrm{C}_{3} \mathrm{~N}_{4}$-ZnS-DNA nanocomposite. Fig. 7 presents the above-described Z-scheme mechanism for electron transfer in the $\mathrm{g}-\mathrm{C}_{3} \mathrm{~N}_{4}$-ZnS-DNA nanocomposite and the possible electrocatalytic oxidation mechanism of PCP and NP.

\subsection{Limits of detection of PCP and NP}

To develop a voltammetric methodology for the determination of hormones in environmental water samples at g- $\mathrm{C}_{3} \mathrm{~N}_{4}$-ZnS-DNA-GCE, we selected DPV mode because the peaks were sharp and well defined at lower concentrations of environmental hormones. Fig. 8 shows the DPV curves of NP and PCP solutions, respectively. The insets in Fig. 8 show the calibration plots constructed from the DPV responses for NP and PCP. Two linear equations were obtained relating the DPV peak currents and the concentrations of NP and PCP, I $\mathrm{p}_{\mathrm{NP}}=$ $0.0594 C+0.2341(\mathrm{R}=0.9968)$, and $\mathrm{Ip}_{\mathrm{PCP}}=0.1083 C+1.1156(\mathrm{R}$ $=0.9900)$, respectively. The relationships were found to be almost linear in the concentration range from $2.0 \times 10^{-5}$ to $1.0 \times$ $10^{-8} \mathrm{~mol} \mathrm{~L}^{-1}$ and from $1.0 \times 10^{-5}$ to $1.0 \times 10^{-8} \mathrm{~mol} \mathrm{~L}^{-1}$ for NP and PCP, respectively. Meanwhile, the limit of detection $(\mathrm{S} / \mathrm{N}=$ 3) was determined to be an average of about $3.3 \times 10^{-9} \mathrm{~mol} \mathrm{~L}^{-1}$ for these two environmental hormones. This result was superior to previously reported values $[35,36]$. Additionally, the reproducibility and stability of g- $\mathrm{C}_{3} \mathrm{~N}_{4}-\mathrm{ZnS}$-DNA-GCE were evaluated with a CV method under optimized conditions. The reproducibility, expressed in terms of relative standard deviation (RSD), of the same electrode in 10 successive measurements was about $3.5 \%$. The stability of the g- $\mathrm{C}_{3} \mathrm{~N}_{4}$-ZnS-DNA-GCE was also investigated by DPV. The nanocomposite-modified electrode retained about $91.6 \%$ of its initial response to the same standard solution after a month, a result was slightly better than that obtained by Wei and co-authors [37]. The same modified electrode retained about $95.2 \%$ of its initial response to the same real sample solution after $10 \mathrm{~d}$, and the RSD of the DPV peak current was about
$1.6 \%$. These results indicated that g- $\mathrm{C}_{3} \mathrm{~N}_{4}-\mathrm{ZnS}$-DNA-GCE exhibited excellent reproducibility and stability, and could be used for practical applications.

Furthermore, to evaluate the practical performance of g- $\mathrm{C}_{3} \mathrm{~N}_{4}$-ZnS-DNA-GCE in real applications, we employed the DPV method to detect NP and PCP in different lake water samples. For NP, the recoveries of school lake water and east lake water were about $98.1 \%-108.7 \%$ and $90.4 \%-98.3 \%$, respectively. For PCP, the recoveries of school lake water and east lake water were about $99.5 \%-104.7 \%$ and $94.2 \%-115 \%$, respectively. These results indicated that g- $\mathrm{C}_{3} \mathrm{~N}_{4}-\mathrm{ZnS}$-DNA-GCE showed a good practicability for PCP and NP detection. Therefore, the quantitative electrochemical analysis of hormones in environmental water samples is feasible using the present g- $\mathrm{C}_{3} \mathrm{~N}_{4}$-ZnS-DNA electrode.

\section{Conclusions}

We have demonstrated a facile route for the preparation of g- $\mathrm{C}_{3} \mathrm{~N}_{4}$-ZnS-DNA nanocomposites. The physical and chemical properties of the g- $\mathrm{C}_{3} \mathrm{~N}_{4}-\mathrm{ZnS}$-DNA nanocomposite indicated that it possessed an enhanced ORR activity. Moreover, the g- $\mathrm{C}_{3} \mathrm{~N}_{4}$-ZnS-DNA-GCE exhibited superior electrocatalytic performance to that of pure g- $\mathrm{C}_{3} \mathrm{~N}_{4}, \mathrm{ZnS}$, and some previously reported electrochemical sensors. The potential of the present system as a sensing material for environmental hormones based on electrocatalytic performance was explored and satisfactory results were obtained. We believe that the present g- $\mathrm{C}_{3} \mathrm{~N}_{4}$-ZnS-DNA nanocomposite is a promising support material for electrocatalytic applications.

\section{References}

[1] H. Kato, K. Asakura, A. Kudo, J. Am. Chem. Soc., 2003, 125, 3082-3089.

[2] S. C. Mojumdar, L. Raki, J. Therm. Anal. Calorim., 2006, 86, 651-657.

[3] U. Baruah, D. Chowdhury, RSC Adv., 2016, 6, 67102-67112. 


\title{
Graphical Abstract
}

Chin. J. Catal., 2017, 38: 287-295 doi: 10.1016/S1872-2067(16)62582-2

Preparation and application of $\mathrm{g}-\mathrm{C}_{3} \mathrm{~N}_{4}$-ZnS-DNA nanocomposite with enhanced electrocatalytic activity

Xin Zhou, Jing Zou*, Sheng Zhang, Ming Pan, Wanyun Gong Wuhan Institute of Technology

A g- $\mathrm{C}_{3} \mathrm{~N}_{4}$-ZnS-DNA nanocomposite was prepared by a simple method. The possible Z-scheme mechanism for electron transfer in the g- $\mathrm{C}_{3} \mathrm{~N}_{4}$-ZnS-DNA nanocomposite and the possible mechanism for electrocatalytic oxidation of PCP and NP were proposed.

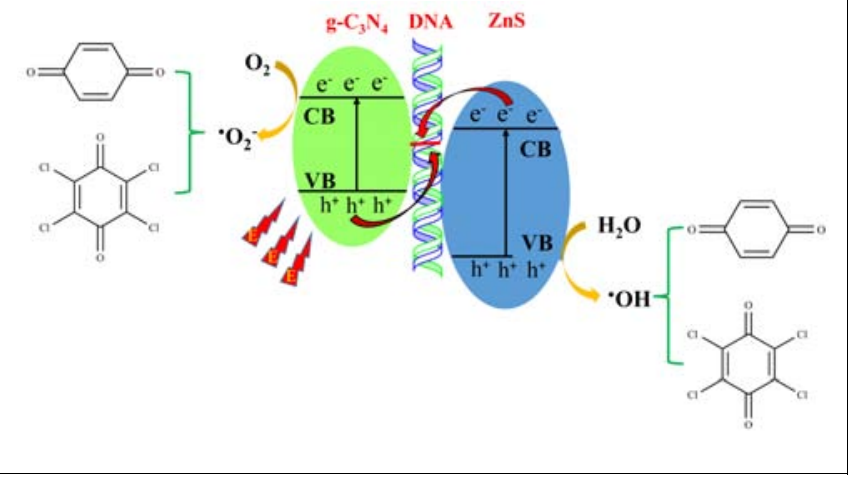

1488-1491.

[23] F. Yang, M. Lublow, S. Orthmann, C. Merschjann, T. Tyborski, M. Rusu, S. Kubala, A. Thomas, R. Arrigo, M. Hävecker, T. Schedel-Niedrig, ChemSusChem, 2012, 5, 1227-1232.

[24] Y. D. Hou, A. B. Laursen, J. S. Zhang, G. G. Zhang, Y. S. Zhu, X. C. Wang, S. Dahl, I. Chorkendorff, Angew Chem. Int. Ed., 2013, 52, 3621-3625.

[25] J. S. Zhang, M. Grzelczak, Y. D. Hou, K. Maeda, K. Domen, X. Z. Fu, M. Antonietti, X. C. Wang, Chem. Sci., 2012, 3, 443-446.

[26] J. Fu, Y. L. Tian, B. B. Chang, F. N. Xi, X. P. Dong, J. Mater. Chem., 2012, 22, 21159-21166.

[27] S. E. Beck, R. A. Rodriguez, K. G. Linden, T. M. Hargy, T. C. Larason, H. B. Wright, Environ. Sci. Technol., 2013, 48, 591-598.

[28] X. Q. Lin, X. H. Jiang, L. P. Lu, Biosens. Bioelectron. 2005, 20, 1709-1717.

[29] F. F. Shi, L. L. Chen, C. S. Xing, D. L. Jiang, D. Li, M. Chen, RSC Adv., 2014, 4, 62223-62229.

[30] P. Suyana, S. K. Sneha, B. N. Nair, V. Karunakaran, A. P. Mohamed, K. G. K. Warrier, U. S. Hareesh, RSC Adv., 2016, 6, 17800-17809.

[31] X. B. Chen, P. A. Glans, X. F. Qiu, S. Dayal, W. D. Jennings, K. E. Smith, C. Burda, J. H. Guo, J. Electron Spectrosc. Relat. Phenomena, 2008, 162, 67-73.

[32] A. Thomas, A. Fischer, F. Goettmann, M. Antonietti, J. O. Müller, R. Schlögl, J. M. Carlsson, J. Mater. Chem., 2008, 18, 4893-4908.

[33] J. Z. Jiang, L. H. Zhu, J. Zou, O. Y. Lei, A. M. Zheng, H. Q. Tang, Carbon, 2015, 87, 193-205.

[34] D. H. Guo, R. Shibuya, C. Akiba, S. Saji, T. Kondo, J. Nakamura, Science, 2016, 351, 361-365.

[35] Y. H. Wu, Sensor Actuat. B, 2009, 137, 180-184.

[36] J. D. Huang, X. M. Zhang, S. Liu, Q. Lin, X. R. He, X. R. Xing, W. J. Lian, D. Tang, Sensor Actuat. B, 2011, 152, 292-298.

[37] S. L. Yang, B. Y. Xia, X. D. Zeng, S. L. Luo, W. Z. Wei, X. Y. Liu, Anal. Chim. Acta, 2010, 667, 57-62.

\section{具有高电催化活性的g- $\mathrm{C}_{3} \mathrm{~N}_{4}-\mathrm{ZnS}-\mathrm{DNA}$ 纳米复合材料的制备及应用}

\author{
周 金金, 邹 菁*, 张 胜, 潘 敏, 龚晚芸 \\ 武汉工程大学化学与环境工程学院, 绿色化学过程教育部重点实验室, 湖北武汉430205
}

摘要: g- $\mathrm{C}_{3} \mathrm{~N}_{4}$ 作为丰富的可见光光催化剂, 具有独特的二维结构, 优异的化学稳定性和可调的电子结构; 但因其激子结合能 高和结晶度较低, 导致其光催化过程量子效率偏低, 限制了光催化剂的推广应用. 根据g- $\mathrm{C}_{3} \mathrm{~N}_{4}$ 独特的可调电子结构, 将其与 半导体材料进行耦合, 形成异质结构, 通过调控半导体的能带结构, 优化其光吸收能力, 促进光生电子-空穴对的快速分离, 
从而抑制光生载流子的复合, 提高其光催化效率. 目前, 人们已发展了许多 $\mathrm{g}_{-} \mathrm{C}_{3} \mathrm{~N}_{4}$ 与窄禁带和宽禁带半导体耦合形成的二 元纳米复合材料, 广泛应用于光催化降解污染物、光催化水解产氢和光催化还原将温室气体 $\mathrm{CO}_{2}$ 转换成有用的碳氢燃料等 方面, 但关于 $\mathrm{g}-\mathrm{C}_{3} \mathrm{~N}_{4}$ 基的三元复合光催化剂, 尤其与天然纳米材料DNA复合, 研究其电催化性能的却鲜有报道. 近年来, 随 着环境污染日益严重, 被称为环境激素的五氯酚( $\mathrm{PCP}$ )、壬基酚 $(\mathrm{NP})$ 等一系列环境激素在水体和土壤等环境介质中长期残 留, 难以降解, 且容易聚集在生物体内, 通过空气循环和食物链等方式进入人体, 对环境和人体产生极大的危害, 所以越来 越多的人致力于环境激素的高效篮选和检测的研究. 常规的分析方法已经很难满足人们对环境激素的高灵敏检测的要求, 而电化学方法因其操作简单、成本低廉、选择性好、灵敏度高、样品前处理简单等特点而备受关注.

本文成功设计和制备了 $\mathrm{g}-\mathrm{C}_{3} \mathrm{~N}_{4}-\mathrm{ZnS}-\mathrm{DNA}$ 三元纳米复合材料. 首先, 采用水热法制备了 $\mathrm{ZnS}$ 半导体纳米片, 采用热解法 制备了g- $\mathrm{C}_{3} \mathrm{~N}_{4}$ 纳米片, 接着将它们与DNA复合, 成功制备了 g- $\mathrm{C}_{3} \mathrm{~N}_{4}-\mathrm{ZnS}-\mathrm{DNA}$ 纳米复合材料, 通过苯胺聚合法修饰到玻碳电 极表面, 成功构建了NP和PCP环境激素新型的电化学传感器. 通过透射电镜、X射线衍射、紫外-可见漫反射光谱和X射线 光电子能谱等对其形貌、结构及组分进行了表征. 采用CHI660C仪器对新型的电化学传感器的电催化性能进行了系统研 究. 通过循环伏安法 $(C V)$ 和示差脉冲伏安法(DPV)研究了NP和PCP在 $g-\mathrm{C}_{3} \mathrm{~N}_{4}-Z n S-D N A-G C E$ 修饰电极的上的电化学行为.

电化学阻抗谱表明, g- $\mathrm{C}_{3} \mathrm{~N}_{4}-\mathrm{ZnS}-\mathrm{DNA}$ 纳米复合材料大大促进了修饰电极的电子传递能力, 与 $\mathrm{g}-\mathrm{C}_{3} \mathrm{~N}_{4}$ 膜相比, $\mathrm{ZnS}$ 和 DNA 共掺杂的g- $\mathrm{C}_{3} \mathrm{~N}_{4}$ 膜对 NP和PCP的电化学响应明显提高, 峰电流是 $g-\mathrm{C}_{3} \mathrm{~N}_{4}$ 膜的 2 倍, 电催化活性明显增强. 在最优化条件 下, NP和PCP检测的线性范围分别为 $2.0 \times 10^{-5}-1.0 \times 10^{-8}$ 和 $1.0 \times 10^{-5}-1.0 \times 10^{-8} \mathrm{~mol} \mathrm{~L}^{-1}$, 检出限均为 $3.3 \times 10^{-9} \mathrm{~mol} \mathrm{~L}^{-1}$. 将 g- $\mathrm{C}_{3} \mathrm{~N}_{4}-\mathrm{ZnS}$-DNA-GCE修饰电极用于湖水中NP和PCP的测定, 其回收率均高于 $90 \%$, 证明g- $\mathrm{C}_{3} \mathrm{~N}_{4}-\mathrm{ZnS}$-DNA纳米复合材料修 饰电极可应用实际水样中痕量环境激素的测定. 同时, 我们分析了电催化活性增强的原因: (1) DNA分子通过C-O-C键连 接到 $\mathrm{g}-\mathrm{C}_{3} \mathrm{~N}_{4}$ 表面, 导致ZnS纳米片组装成线性超结构, 形成稳定的 $\mathrm{g}-\mathrm{C}_{3} \mathrm{~N}_{4}-\mathrm{ZnS}-\mathrm{DNA}$ 纳米复合材料; (2) 由于DNA和PCP或 $\mathrm{NP}$ 之间的相互作用使得电极表面上的PCP和NP的浓度增加; (3) 纳米复合材料聚苯胺膜可促进电子转移和加速 PCP或NP 向电极表面的扩散; 并提出了 Z 型 $\mathrm{g}-\mathrm{C}_{3} \mathrm{~N}_{4}-\mathrm{ZnS}-\mathrm{DNA}$ 纳米复合材料的电子转移路径, 以及PCP和NP的可能的电催化氧化机 理.

关键词: 氮化碳; 硫化锌; DNA; 纳米复合材料; 电催化活性; 环境激素

收稿日期: 2016-09-29. 接受日期: 2016-10-24. 出版日期: 2017-02-05.

*通讯联系人. 电话/传真: (027)81624593; 电子信箱: jingzou@wit.edu.cn

基金来源: 国家自然科学基金(21471122), 武汉工程大学研究生教育创新基金及校长基金(CX2015147, 2016062).

本文的英文电子版由Elsevier出版社在ScienceDirect上出版(http://www.sciencedirect.com/science/journal/18722067). 